\title{
The range of linguistic units: Distance effects in English mandative subjunctive constructions - CORRIGENDUM
}

\author{
THOMAS BERG \\ University of Hamburg \\ TIM ZINGLER \\ University of New Mexico \\ ARNE LOHMANN \\ University of Düsseldorf
}

doi:10.1017/S0022226719000124, published online by Cambridge University Press, 17 April 2019.

In the Journal of Linguistics article 'The range of linguistic units: Distance effects in English mandative subjunctive constructions' by Thomas Berg, Tim Zingler \& Arne Lohmann, the References entry for the Ruohonen 2018 citation should read as follows:

Ruohonen, Juho. 2018. 21st-century trends in BrE mandative constructions: A statistical multivariate analysis. Presented at the 5th Conference of the International Society for the Linguistics of English, London.

\section{REFERENCE}

Berg, Thomas, Tim Zingler \& Arne Lohmann. The range of linguistic units: Distance effects in English mandative subjunctive constructions. Journal of Linguistics, doi:10.1017/S0022226719000124. Published online by Cambridge University Press, 17 April 2019. 